\title{
Status gizi, asupan energi, dan serat sebagai faktor risiko kardiometabolik pada remaja pendek
}

\author{
Nutritional status, energy and fiber intake as cardiometabolic risk factors in stunting adolescent \\ Siti Nur Fatimah ${ }^{1}$ Ambrosius Purba ${ }^{2}$, Kusnandi Rusmil ${ }^{3}$, Gaga Irawan Nugraha ${ }^{4}$ \\ 'Departemen Ilmu Kesehatan Masyarakat dan Kedokteran Pencegahan, Fakultas Kedokteran Universitas Padjadjaran \\ 2Departemen Anatomi Fisiologi dan Biologi Sel, Fakultas Kedokteran Universitas Padjadjaran \\ Departemen Ilmu Kesehatan Anak, Fakultas Kedokteran Universitas Padjadjaran \\ ${ }^{4}$ Departemen Biomikia dan Biologi Molekuler, Fakultas Kedokteran Universitas Padjadjaran
}

\begin{abstract}
Background: Prevalence of stunted adolescents is important because related with cardiometabolic risk factor. Control of risk factors reduce the comorbidity including body mass index (BMI) control. Improvement of environmental factors such as energy and fiber intake contribute to reduce disease risk. Objective: This study aimed to analyze the relationship of stunted adolescent with BMI, energy and fiber intake. Method: This study used cross-sectional design. The subject consisted of early adolescents with 10 to 14 years old. Determination of short stature and BMI refers to the WHO Growth Chart 2005. Data collection by measure of height, weight, BMI calculation, and interviewed food intake by $3 \times 24$ hour food recall and analyzed with Nutrisurvey program. Statistical analysis by Mann-Whitney U test. Results: A total of 212 participants (106 stunted and 106 non-stunted) were enrolled. The proportion of stunted girls is 58 (54.9\%) and stunted boys 48 (45.1\%). Average of BMI in stunted is 17.15 (SD \pm 2.59$) \mathrm{kg} / \mathrm{m}^{2}$ and 18.38 (SD \pm 3.33 ) $\mathrm{kg} / \mathrm{m}^{2}$ in non-stunted, energy intake is 1488.83 ( $\left.S D \pm 513.52\right) \mathrm{kcal}$ in stunted and 1704.32 (SD \pm 663.49$)$ in non-stunted, fiber intake is 4,36 ( $S D \pm 1.18) \mathrm{g}$ in stunted and 4.53 ( $S D \pm 2.15) \mathrm{g}$ in non stunted. There are significant differences in all variables between stunted and non-stunted (BMI $p=0.017$; energy intake $p=0.03$; fiber intake $p=0.032$ ). BMI showed the correlation with disease risk including cardiometabolic diseases in stunting. Energy intake and low fiber in growth age increase risk of cardiometabolic diseases because in stunting have low metabolic adaptation in protein synthesis and fat oxidation. Conclusion: The study shows there was a difference between BMI, energy intake and fiber in the stunted adolescent and non-stunted adolescent.
\end{abstract}

KEY WORDS: BMI; early adolescent; energy intake; fiber intake; stunting

\section{ABSTRAK}

Latar belakang: Prevalensi remaja pendek merupakan masalah kesehatan penting karena berhubungan dengan risiko penyakit kardiometabolik. Pengendalian faktor risiko dapat membantu menurunkan komorbiditas penyakit termasuk pengendalian indeks massa tubuh (IMT). Faktor lingkungan seperti asupan kalori dan serat berkontribusi menurunkan risiko penyakit. Tujuan: Menganalisis hubungan tinggi badan dengan IMT, asupan energi, dan serat sebagai salah satu faktor risiko kardiometabolik. Metode: Penelitian berdesain potong lintang dengan subjek penelitian adalah remaja awal pendek berusia 10-14 tahun. Penentuan perawakan pendek dan IMT dilakukan dengan pengukuran tinggi dan berat badan yang mengacu pada standar WHO Growth Chart 2005. Pengambilan data asupan makanan dilakukan dengan recall 3x24 jam dan dianalisis dengan Nutrisurvey Analisis bivariat dengan uji Mann Whitney U. Hasil: Diperoleh 212 subjek dengan proporsi remaja pendek dan kontrol sama. Proporsi remaja awal pendek pada remaja perempuan sebesar $58(54,9 \%)$ dan $48(45,1 \%)$ pada remaja laki-laki. Rerata IMT pada remaja pendek adalah $17,15(\mathrm{SD} \pm 2,59) \mathrm{kg} / \mathrm{m}^{2}$ dan pada tinggi badan normal 18,38 $(\mathrm{SD} \pm 3,33) \mathrm{kg} / \mathrm{m}^{2}$. Rerata asupan energi $1.488,83(\mathrm{SD} \pm 513,52) \mathrm{kkal}$ pada remaja pendek dan $1.704,32(\mathrm{SD} \pm 663,49) \mathrm{kkal}$ pada tinggi badan normal. Rerata asupan serat 4,36 $(\mathrm{SD} \pm 1,18) \mathrm{g}$ pada remaja pendek dan 4,53 $(\mathrm{SD} \pm 2,15) \mathrm{g}$ pada tinggi badan normal. Terdapat perbedaan bermakna pada semua variabel yang diteliti yaitu $\operatorname{IMT}(\mathrm{p}=0,017)$; asupan energi $(\mathrm{p}=0,034)$; dan asupan serat $(\mathrm{p}=0,032)$. IMT menunjukkan kecenderungan risiko penyakit termasuk penyakit kardiometabolik pada remaja pendek. Asupan energi dan serat yang rendah pada remaja pendek akan meningkatkan risiko penyakit kardiometabolik karena perawakan pendek memiliki adaptasi metabolik yang rendah terhadap optimalnya sintesis 
protein dan oksidasi lemak. Simpulan: Studi ini menunjukkan adanya perbedaan antara IMT, asupan energi, dan serat antara remaja pendek dan remaja dengan tinggi badan normal.

KATA KUNCI: IMT; remaja awal; asupan energi; asupan serat; pendek

\section{PENDAHULUAN}

Tinggi badan merupakan salah satu parameter penting yang mempengaruhi status kesehatan karena selain menggambarkan kegagalan pertumbuhan linier, juga menggambarkan immaturitas organ dan risiko rendahnya adaptasi metabolik. Hal ini terbukti dengan tingginya korelasi antara perawakan pendek dengan risiko penyakit menular dan penyakit degeneratif $(1,2)$. Perawakan pendek masih menjadi salah satu masalah kesehatan yang belum mencapai penurunan memuaskan. Indonesia menempati urutan kelima terbanyak populasi perawakan pendek di dunia. Data The United Nations International Children's Emergency Fund (UNICEF) tahun 2010 menemukan prevalensi perawakan pendek di Indonesia mencapai 36\% (3). Tinggi badan pada usia remaja perlu menjadi perhatian penting karena berada pada tahap akhir masa tumbuh kejar. Perbaikan berbagai faktor yang mempengaruhi kecepatan pertumbuhan diharapkan dapat membantu mengoptimalkan potensi pertumbuhan dan menurunkan risiko komorbiditas (4). Data Riset Kesehatan Dasar (Riskesdas) tahun 2013 menunjukkan prevalensi perawakan pendek pada remaja awal laki-laki adalah 32,3-40,2\% dan perempuan sebesar $32,8-35,8 \%(5)$.

Berbagai faktor risiko yang berhubungan dengan perawakan pendek antara lain risiko hipertensi lebih tinggi terjadi pada remaja pendek dengan berat badan lebih. Penelitian lain menyatakan bahwa pendek juga berhubungan dengan risiko resistensi insulin. Kedua hal tersebut berhubungan dengan risiko komplikasi kardiometabolik serius sehingga akan menurunkan produktivitas dan kualitas hidup. Lebih jauh dinyatakan bahwa perawakan pendek berhubungan dengan kegagalan performa psikologis dan fungsi kognisi. Risiko komplikasi obstetri buruk juga terjadi pada remaja perempuan dan wanita usia subur dengan perawakan pendek $(1,6,7)$. Status gizi berhubungan dengan risiko penyakit menular dan tidak menular pada setiap kelompok usia. Status gizi lebih maupun kurang pada remaja pendek berhubungan dengan risiko penyakit menular dan tidak menular. Penelitian pada anak di Afrika Selatan menunjukkan terdapat hubungan antara status gizi pada perawakan pendek dengan risiko penyakit menular dan tidak menular (8).

Remaja awal dengan umur 10 sampai 14 tahun sedang mengalami masa tumbuh kejar tahap akhir sehingga segala sesuatu yang menunjang pertumbuhan optimal akan berpengaruh. Di sisi lain, perkembangan remaja awal yang masih pada tahap peralihan dari anakanak ke dewasa sangat berpengaruh pada gaya hidup dan pola makan. Asupan gizi sebagai salah satu faktor lingkungan masih menjadi masalah penting pada usia pertumbuhan. Berbagai penelitian menyatakan bahwa asupan energi yang kurang selama masa pertumbuhan berperan penting terhadap terjadinya perawakan pendek $(4,9,10)$.

Lebih lanjut, asupan serat pangan yang cukup akan membantu mengoptimalkan proses metabolisme dengan membantu optimalnya milieu di saluran cerna dan membantu menurunkan berbagai risiko penyakit. Data Riskesdas 2013 memberi gambaran proporsi asupan bahan makanan sumber sayur dan buah yang kurang di Jawa Barat mencapai 97\%, lebih rendah dibanding proporsi asupan sumber sayur dan buah secara nasional di Indonesia yang kurang yaitu 93\% (5). Dengan demikian, penelitian ini bertujuan untuk menganalisis perbedaan IMT, asupan energi, dan serat sebagai faktor risiko kardiometabolik pada remaja awal pendek dan remaja dengan tinggi badan normal.

\section{BAHAN DAN METODE}

Desain penelitian ini adalah analitik observasional dengan metode potong lintang. Penelitian ini merupakan bagian dari Jatinangor Growth Study di bawah Pusat Studi Kesehatan Kebugaran Komunitas Fakultas Kedokteran Universitas Padjadjaran. Penelitian dilakukan di sekolah dasar dan sekolah menengah pertama Kecamatan Jatinangor Kabupaten Sumedang Propinsi 
Jawa Barat. Waktu penelitian pada bulan Oktober 2014 sampai bulan Februari 2015. Populasi penelitian adalah seluruh remaja awal berumur 10 sampai 14 tahun baik laki-laki maupun perempuan yang merupakan penduduk Kecamatan Jatinangor dan bersekolah di SD atau SMP di Kecamatan Jatinangor. Subjek penelitian adalah populasi penelitian yang terpilih menjadi subjek penelitian dengan krieria inklusi dan kriteria eksklusi. Jumlah subjek penelitian dihitung dengan rumus besar sampel untuk melihat prevalensi, ditetapkan jumlah sampel 96 ditambah 10\% menjadi 106 pada setiap kelompok remaja pendek dan normal untuk antisipasi data subjek yang berkurang karena drop out (11). Metode pengambilan subjek penelitian dilakukan dengan metode stratified random sampling. Kriteria inklusi subjek penelitian adalah remaja awal laki-laki dan perempuan dengan rentang usia 10 sampai 14 tahun, berdomisili di wilayah penelitian, dan sehat. Kriteria eksklusi subjek penelitian adalah memiliki postur tubuh yang tidak normal sehingga tidak memungkinkan diperiksa tinggi badan.

Variabel tinggi badan diketahui berdasarkan hasil pengukuran maksimum panjang tulang secara paralel yang membentuk poros tubuh, yaitu diukur dari titik tertinggi di kepala/vertex, ke titik terendah dari tulang kalkaneus. Penentuan indeks massa tubuh (IMT) dengan acuan WHO Growth Chart 2005, sementara asupan energi dan serat yang dikonsumsi subjek dalam sehari diketahui berdasarkan hasil recall 3×24 jam dengan salah satu harinya adalah hari libur. Alat ukur tinggi badan dengan stadiometer tipe 213 dan berat badan dengan bioimpedance analyzer (BIA). Asupan makanan diketahui dengan wawancara menggunakan form recall dan food model.

Pengambilan data dilakukan dengan melengkapi data umum, selanjutnya dilakukan pengukuran tinggi badan, berat badan dan wawancara asupan makanan. Pengukuran tinggi badan dilakukan dengan cara subjek melepaskan alas kaki, pada saat pengukuran, subjek berdiri tegak dengan posisi kepala menghadap lurus ke depan, kaki merapat dan tulang belikat, pinggul serta bahu menempel ke alat pengukur dengan kedua lengan tergantung bebas disamping tubuh. Bagian yang dapat bergerak dari stadiometer diturunkan hingga menyentuh vertex dan diturunkan hingga menekan rambut. Hasil pengukuran dibaca dan dicatat di formulir. Penentuan stunting ditentukan dengan mengacu pada referensi $W H O$ Growth Chart 2005, yaitu kriteria stunting jika di bawah nilai 2 simpang baku $(12,13)$. Sementara hasil wawancara asupan gizi dicatat pada formulir asupan gizi, jumlah asupan gizi dihitung dengan mengkonversi besar asupan makanan dalam bentuk ukuran rumah tangga (URT) ke dalam bentuk gram terlebih dahulu, kemudian dilakukan perhitungan jumlah asupan gizi (dalam gram) dengan menggunakan Nutrisurvey for Windows 2005.

Analisis univariat untuk menganalisis karakteristik jenis kelamin, usia, sebaran tinggi badan, berat badan, IMT, asupan energi dan asupan serat. Analisis bivariat dengan uji Mann Whitney $U$ bila distribusi data tidak normal. Penelitian pada subjek akan dilakukan jika responden dan orang tua responden menyatakan setuju untuk terlibat sebagai subjek penelitian dengan menandatangani surat persetujuan penelitian.

\section{HASIL}

Seluruh data penelitian dapat diperoleh lengkap sehingga terkumpul masing-masing 106 subjek penelitian yang dianalisis untuk setiap kelompok. Hasil penelitian menunjukkan proporsi jenis kelamin remaja laki-laki pendek lebih tinggi dari remaja laki-laki normal dan proporsi remaja perempuan pendek lebih rendah dari remaja perempuan normal. Sebaran rerata berat badan pada remaja pendek lebih rendah dari normal. Demikian pula sebaran status gizi kurus lebih tinggi pada remaja pendek daripada remaja normal. Karakteristik subjek penelitian tercantum dalam Tabel 1.

Tabel 1. Karakteristik umum subjek penelitian

\begin{tabular}{|c|c|c|}
\hline Variabel & Pendek & Normal \\
\hline Jumlah subjek (n,\%) & $106(50)$ & $106(50)$ \\
\hline \multicolumn{3}{|l|}{ Jenis kelamin $(\mathrm{n}, \%)$} \\
\hline Laki-laki & $48(45,1)$ & $40(39,4)$ \\
\hline Perempuan & $58(54,9)$ & $66(60,0)$ \\
\hline Umur (tahun) $)^{1}$ & $12,45(1,18)$ & $12,04(1,15)$ \\
\hline Tinggi badan $(\mathrm{cm})^{1}$ & $137,34(7,22)$ & $148,97(7,59)$ \\
\hline Berat badan $(\mathrm{kg})^{1}$ & $32,71(7,02)$ & $40,95(9,68)$ \\
\hline Indeks massa tubuh $\left(\mathrm{kg} / \mathrm{m}^{2}\right)^{1}$ & $17,15(2,59)$ & $18,38(3,33)$ \\
\hline \multicolumn{3}{|l|}{ Kategori status gizi (n,\%) } \\
\hline Kurus & $17(15,5)$ & $15(14,1)$ \\
\hline Normal & $89(84,5)$ & $91(85,9)$ \\
\hline
\end{tabular}

${ }^{1}$ data dalam rerata $(\mathrm{SD})$ 
Tabel 2. Perbedaan sebaran IMT, asupan energi dan serat pada remaja awal pendek dan tinggi badan normal

\begin{tabular}{lccc}
\hline \multirow{2}{*}{ Variabel } & Pendek & Normal & p \\
\cline { 2 - 4 } & Rerata $\left(\mathbf{S D}^{1}\right)$ & Rerata $($ SD) & \\
\hline IMT $\left(\mathrm{kg} / \mathrm{m}^{2}\right)$ & $17,15(2,59)$ & $18,38(3,33)$ & $0,017^{*}$ \\
Energi $(\mathrm{kkal})$ & $1.488,83(513,52)$ & $1.704,32(663,49)$ & $0,034^{*}$ \\
Serat $(\mathrm{g})$ & $4,36(1,18)$ & $4,53(2,15)$ & $0,032^{*}$ \\
\hline
\end{tabular}

${ }^{1} \mathrm{SD}=$ standar deviasi; *Uji Mann-Whitney $U$, bermakna $(\mathrm{p}<0,05)$

Uji Kolmogorof-Smirnov dilakukan untuk melihat distribusi data dan diperoleh nilai $\mathrm{p}$ kurang dari 0,05 . Selanjutnya, dilakukan transformasi data tetapi hasil uji normalitas tidak memenuhi untuk dilakukan uji parametri. Analisis bivariat dilakukan dengan uji Mann-Whitney $U$ untuk melihat perbedaan rerata IMT, asupan energi, dan serat antara kelompok remaja awal pendek dan normal. Tabel 2 menunjukkan perbandingan rerata IMT pada remaja pendek dan normal yang memperlihatkan adanya perbedaan rerata IMT pada remaja awal pendek dan normal $(p=0,017)$. Demikian juga dengan rerata asupan energi dan serat yang menunjukkan adanya perbedaan rerata asupan energi dan serat pada remaja awal pendek dan normal $(\mathrm{p}<0,05)$.

\section{BAHASAN}

Proporsi remaja awal pendek dari hasil penelitian menunjukkan lebih tinggi pada remaja perempuan dibanding remaja laki-laki. Data Riskesdas 2013 memperlihatkan proporsi remaja pendek lebih tinggi pada perempuan untuk usia 10 sampai 11 tahun dan lebih tinggi pada laki-laki untuk usia 12 sampai 14 tahun (5). Pertumbuhan pada remaja awal mulai dipengaruhi oleh hormon reproduksi untuk maturasi organ reproduksi, selain pengaruh hormon pertumbuhan. Pengaruh hormon ini akan meningkatkan deposisi massa bebas lemak pada laki-laki dengan meningkatnya pertumbuhan tulang dan otot sedangkan pada perempuan akan lebih meningkatkan deposisi lemak pada area tertentu $(4,5,14)$.

Rerata umur pada penelitian ini cukup homogen karena diambil subjek kelompok remaja awal dengan umur 10 sampai 14 tahun. Data Riskesdas 2013 menunjukkan pada anak laki-laki, prevalensi pendek tertinggi di umur 13 tahun (40,2\%) sedangkan pada anak perempuan di umur 11 tahun (35,8\%). Karakteristik fisiologis kelompok ini ditandai dengan meningkatnya aktivitas hormon pertumbuhan dan dimulainya sekresi dan aktivitas hormon reproduksi. Kecepatan pertumbuhan pada remaja perempuan terjadi lebih awal yaitu antara umur 10 sampai 12 tahun sedangkan pada remaja laki-laki antara umur 12 sampai 14 tahun $(4,5,10,15)$. Rerata tinggi badan pada kelompok pendek adalah 137,34 (SD 7,22) cm dan 148,97 (SD 7,59) cm pada kelompok kontrol. Rerata tinggi badan ini masih jauh di bawah rujukan WHO tahun 2007. Sebaran tinggi badan masih belum menunjukkan perbaikan, menurut data Riskesdas 2007, 2010, dan 2013 memperlihatkan proporsi pendek pada anak dan remaja rentang usia 5 sampai 18 tahun adalah $36,8 \% ; 35,6 \%$; dan $37,2 \%(5,16,17)$.

Sebaran IMT pada remaja pendek adalah 17,15 $(\mathrm{SD} 2,59) \mathrm{kg} / \mathrm{m}^{2}$ dan $18,38(\mathrm{SD} 3,33) \mathrm{kg} / \mathrm{m}^{2}$ pada tinggi badan normal. Analisis statistik menunjukkan terdapat perbedaan sebaran IMT pada remaja pendek dan tinggi badan normal. Indeks massa tubuh sebagai salah satu parameter status gizi menunjukkan kecenderungan risiko penyakit. Status gizi berdasarkan kategori IMT/Umur menurut WHO Growth Chart 2007 menunjukkan 15,5\% kurus pada remaja pendek dan 14,1\% kurus pada remaja normal. Hal ini menunjukkan kecenderungan status gizi kurus lebih tinggi pada remaja pendek dibanding remaja normal. Berbagai penelitian memperlihatkan IMT dibawah normal berhubungan dengan deposisi protein yang kurang sehingga akan berisiko menurunnya respon immunitas. Risiko penyakit tidak menular juga meningkat karena dengan terganggunya deposisi protein menyebabkan meningkatnya simpanan sumber energi dalam bentuk lemak. Namun, kedua hal ini akan berisiko gangguan metabolik dan chronic low grade inflamation sehingga meningkatkan risiko penyakit kardiometabolik. $(6,10,17,18)$.

Sebaran asupan kalori pada penelitian ini menunjukkan adanya perbedaan asupan energi yaitu $1.488,83$ (SD 513,52) kkal pada remaja pendek dan 1.704,32 (SD 663,49) kkal pada tinggi badan normal. Penelitian menunjukkan bahwa asupan gizi kurang berhubungan dengan perawakan pendek, penelitian di Nigeria menyatakan bahwa perawakan pendek terkait dengan berat badan kurang dan status gizi kurang (9). Penelitian mengenai karakteristik asupan gizi pada 
perawakan pendek lebih banyak pada balita karena status tinggi badan sangat dipengaruhi oleh kecepatan pertumbuhan pada periode ini (15). Perawakan pendek pada remaja penting diteliti karena di masa ini terjadi masa tumbuh kejar tahap akhir, diketahuinya faktor-faktor yang mempengaruhi pertumbuhan diharapkan menjadi pertimbangan untuk intervensi lebih tepat ataupun perbaikan rekomendasi $(8,9)$.

Maturasi pertumbuhan dan perkembangan pada remaja awal masih pada fase transisi sebelum menuju kematangan sebagai seorang dewasa muda. Hal ini juga mempengaruhi gaya hidup salah satunya pola makan. Masa transisi kematangan jiwa pada periode ini sangat mempengaruhi selera dan pemilihan makanan, pertimbangan kenyamanan dan kemampuan telaah terhadap dampak masa depan masih belum matur sehingga seringkali asupan makanan tidak sesuai kebutuhan baik kuantitas maupun kualitasnya. Pada masa ini kebutuhan gizi sangat esensial karena terjadi kecepatan pertumbuhan massa tulang dan otot, kematangan fungsi organ tubuh, sehingga asupan gizi tidak sesuai akan mempengaruhi proses di atas. Asupan kalori yang cukup diperlukan untuk berbagai proses metabolisme. Apabila hal ini tidak terpenuhi maka efisiensi proses metabolisme tidak adekuat sehingga maturasi organ terganggu dan meningkatkan risiko berbagai penyakit. Hal inilah yang mendasari komorbiditas yang tinggi pada perawakan pendek $(4,15,15,19)$.

Rerata asupan serat adalah 4,36 (SD 1,18) g pada remaja pendek dan 4,53 (SD 2,15) pada remaja normal. Analisis statistik menunjukkan terdapat perbedaan bermakna pada kedua kelompok ini. Karakteristik sebaran asupan menunjukkan hasil yang cukup jauh dari rekomendasi angka kecukupan gizi (AKG) yaitu 28-30 g untuk remaja perempuan dan 30-35 g untuk remaja lakilaki. Rekomendasi lain menyatakan bahwa kebutuhan serat sekitar 0,5 g/kgBB tetapi tidak lebih dari $35 \mathrm{~g} /$ hari untuk menghindari inhibisi absorpsi nutrien esensial oleh fitat dari serat $(20,21)$.Manfaat serat telah banyak diketahui antara lain untuk memperlambat rasa lapar dan memperlambat kemaikan kadar gula darah. Di usus halus, serat tertentu akan berikatan dengan metabolit empedu dan mengganggu siklus enterohepatik. Walaupun tidak mempunyai efek yang besar, tetapi secara kumulatif akan menurunkan risiko berbagai penyakit yang berhubungan dengan kadar lemak berlebih $(2,21)$.

Kelemahan pada penelitian ini adalah tidak dilakukan pengukuran baku emas seperti dietary history dan pemeriksaan laboratorium untuk melihat sebaran variabel yang diukur. Namun, dari gambaran karakteristik ini diharapkan dapat menjadi acuan untuk penelitian berikutnya sehingga dapat dicapai temuan yang lebih jelas hubungan antara asupan gizi dan komorbiditas pada perawakan pendek dan harapannya dapat dilakukan intervensi lebih tepat untuk membantu menurunkan komorbiditas penyakit pada remaja pendek. Secara klinis temuan ini diharapkan menjadi salah satu pertimbangan perbaikan asupan gizi dan penyusunan rekomendasi gizi sehingga tidak menambah masalah kelainan metabolik yang sudah ada pada perawakan pendek.

\section{SIMPULAN DAN SARAN}

Penelitian ini menunjukkan adanya perbedaan antara IMT, asupan energi, dan asupan serat antara remaja pendek dan remaja dengan tinggi badan normal sebagai salah satu faktor risiko antara terhadap penyakit kardiometabolik. Penelitian ini juga memperlihatkan kecenderungan asupan kalori di bawah standar dan asupan serat jauh di bawah standar pada remaja awal pendek. Diperlukan penelitian lebih lanjut untuk melihat analisis hubungan dan efek intervensi yang dianjurkan, baik untuk asupan energi dan serat atau zat gizi lain maupun faktor selain gizi sehingga diperoleh rekomendasi komprehensif untuk kelompok remaja awal yang sedang mengalami masa tumbuh kejar tahap akhir. Efek jangka panjang diharapkan akan membantu mencegah komorbiditas di masa yang akan datang.

\section{UCAPAN TERIMA KASIH}

Penelitian ini terlaksana karena program hibah guru besar dari Prof. Dr. A. Purba, dr, MS, AIFO, hibah internal staf pengajar untuk penulis dari Fakultas Kedokteran Universitas Padjajaran, dan hibah internal Dr. Gaga I Nugraha, dr, MGizi, SpGK. 


\section{Pernyataan konflik kepentingan}

Penulis menyatakan tidak ada konflik kepentingan dengan pihak-pihak yang terkait dalam penelitian ini.

\section{RUJUKAN}

1. Badham J, Sweet L. Stunting: an overview. Sight and Life 2010;3:40-47.

2. Dietz H. Childhood obesity. In: Shills ME, Shike M. Modern nutrition in health and disease $10^{\text {th }}$ Ed. Baltimore: Lipincott Williams \& Wilkins; 2008.

3. United Nations Children Funds. The challange of undernutrition. In: Tracking progress on child and maternal nutrition, a survival and development priority. New York: UNICEF; 2009.

4. Cromer B. Adolescent development. In: Nelson's textbook of pediatrics. 18 ed. Philadelphia: Saunders Elsevier; 2011.

5. Kementerian Kesehatan RI. Riset kesehatan dasar 2013. Jakarta: Badan Penelitian dan Pengembangan Kesehatan Kementerian Kesehatan RI; 2013.

6. Clemente A, Santos C, Silva A, Martins A, Marchesano A, Fernandes M. Mild stunting is associated with higher blood pressure in overweight adolescents. Arq Bras Cardiol 2012;98(1):6-12.

7. Walker S, Chang S, Powell C, Simonoff E, GranthamMcGregor. Early childhood stunting is associated with poor psychological functioning in late adolescence and effects are reduced by psychosocial stimulation. J Nutr 2007;137(11):2464-9.

8. Kimani-Murage EW, Kahn K, Pettifor JM, Tollman SM, Dunger DB, Olive XFE. The prevalence of stunting, overweight and obesity, and metabolic disease risk in rural South African children. BMC Public Health 2010;10:158.

9. Ayoola O, Ebersole K, Omotade O, Tayo BO, Brieger WR, Salami K, et al. Relative height and weight among children and adolescents of rural Southwestern Nigeria. Ann Hum Biol 2009;36(4):388-99.
10. Rakefet P, Galia G, Moshe P. Nutrition and catch-up growth. J Pediatr Gastroenterol Nutr 2010;51(3):S129-30.

11. Sastroasmoro S, Ismael S. Dasar-dasar metodologi penelitian klinis. Jakarta: Sagung Seto; 2002.

12. WHO Multicentre Growth Reference Study Group. WHO child growth standards: length/height-for-age, weight-forage, weightfor-length, weight-for-height and body mass index-for-age:methods and development. [series online] 2006 [cited Sept 2014]. Available from: URL: http://www. int/childgrowth/standards/technical_report/cn/index.html

13. Gibson R. Principles of nutritional assessment. NewYork: Oxford University Press; 2006.

14. Victora CG, Adair L, Fall C, Hallal PC, Martorell R, Richter L. Maternal and child undernutrition: consequencies for adult health and human capital. Lancet 2008; 371(9609):340-57.

15. Dewey KG, Begum K. Why stunting matters. A\&T Technical Brief 2010;2.

16. Kementerian Kesehatan RI. Riset kesehatan dasar 2007. Jakarta: Badan Penelitian dan Pengembangan Kesehatan Kementerian Kesehatan RI; 2007

17. Kementerian Kesehatan RI. Riset kesehatan dasar 2010. Jakarta: Badan Penelitian dan Pengembangan Kesehatan Kementerian Kesehatan RI; 2010

18. Dwi Astuti LM, Prawirohartono EP, Noormanto, Julia M. Obesitas sentral berhubungan dengan toleransi glukosa terganggu pada remaja perempuan. Jurnal Gizi Klinik Indonesia 2012;8(3):113-7.

19. Guyton, Arthur C. Textbook of medical physiology 8th Ed. Philadelphia: W.B. Saunders; 1991.

20. Santos CDL, Clemente APG, Martins VJB, Albuquerque MP, Sawaya AL. Adolescents with mild stunting show alterations in glucose and insulin metabolism. J Nutr Metab 2010 (2010);943070.

21. American Academy of Pediatrics, Committee on Nutrition, and Barness LA. Carbohydrate and dietary fiber. In: Pediatric nutrition handbook 3rd Ed. Elk Grove Village, IL: American Academy of Pediatrics; 1993. 